\title{
THE INVIOLABILITY OF MEDICAL CONFIDENTIALITY IN MALAYSIA: AN ANALYSIS OF THE RULES AND EXCEPTIONS
}

\author{
Puteri Nemie Jahn Kassim* \\ Nazri Ramli**
}

\begin{abstract}
The duty of medical confidentiality has been one of the core duties of medical practice as information created, disclosed, acquired directly or indirectly during the doctor-patient relationship is considered confidential and requires legitimate protection. Further, preserving confidentiality on the premise that the relationship between doctor and patient has been built on trust and confidence renders the duty to be seen as sacrosanct. The source for this duty can be found not only in the Hippocratic Oath, codes of ethics, religious tenets but also in the common law, principles of equity and statutory provisions. Nevertheless, technological advancements and the growth of social networks have contributed to the difficulties in preserving confidentiality as the information gathered tends to become vulnerable in unsecure environments. However, the duty of medical confidentiality is by no means absolute as it can be breached in situations in which there are stronger conflicting duties. This article discusses the rules governing the duty of medical confidentiality and the exceptions in which infringements to this duty become justified. It also gives an overview of the duty of confidentiality under Islamic law. It concludes that the inviolability of this duty may be without doubt but circumstances warranting its disclosure are crucial to serve the interests of justice.
\end{abstract}

Keywords: medical confidentiality, rules, exceptions, medical law, ethical obligations, Malaysia

Professor, Ahmad Ibrahim Kulliyah of Laws, International Islamic University Malaysia.

** Bachelor of Law (Shari'ah) student, Ahmad Ibrahim Kulliyah of Laws, International Islamic University Malaysia. 


\title{
KERAHSIAAN PERUBATAN YANG TIDAK BOLEH DIPERTIKAI DI MALAYSIA: SUATU ANALISIS KAEDAH- KAEDAH DAN PENGECUALIAN
}

\begin{abstract}
ABSTRAK
Kewajipan kerahsiaan perubatan telah menjadi salah satu tugas teras amalan perubatan olehkerana maklumat yang dalam diperolehi secara langsung atau tidak langsung hubungan doktor-pesakit adalah dianggap sulit dan memerlukan perlindungan yang sah. Selanjutnya, memelihara kerahsiaan diatas dasar bahawa hubungan antara doktor dan pesakit telah dibina di atas kepercayaan dan keyakinan menjadikan kewajipan tersebut dianggap mutlak. Sumber kewajipan ini boleh didapati bukan sahaja daripada Sumpah Hippocrates, kod etika, dan hukum agama tetapi juga dalam undang-undang perubatan, prinsip ekuiti dan peruntukan statut. Walau bagaimanapun, kemajuan teknologi dan perkembangan rangkaian sosial telah menyumbang kepada kesukaran dalam memelihara kerahsiaan maklumat yang dikumpul dan maklumat tersebut cenderung terdedah dalam persekitaran yang tidak terjamin. Walau bagaimanapun, kewajipan kerahsiaan perubatan bukanlah mutlak kerana ia boleh dilanggar dalam keadaan di mana terdapat tugas yang lebih kuat yang bertentangan. Makalah ini bertujuan untuk membincangkan kaedah-kaedah yang mengawal kewajipan kerahsiaan perubatan dan pengecualian di mana pelanggaran dengan kewajipan ini menjadi wajar demi menjaga kepentingan keadilan. Ianya juga menyentuh konsep kerahsiaan dalam Undang-undang Islam. Kesimpulannya ialah mungkin tiada keraguan terhadap kemuktamadan kewajipan ini namun keadaan yang mewajarkan pendedahannya masih penting untuk mencapai kepentingan keadilan.
\end{abstract}

Kata kunci: kerahsiaan perubatan, kaedah-kaedah, pengecualian, undang-undang perubatan, etika kewajipan, Malaysia 


\section{INTRODUCTION}

The duty of confidentiality owed by a doctor towards his patient is a relationship built on trust and confidence. This duty creates a trusting environment which encourages patients to share sensitive information and communicate their symptoms, experience, beliefs, concerns and expectations about their illness without fear that the information would be divulged to others. The duty has also been held to be sacrosanct due to its long standing tradition in many codes of ethics for many centuries. The undertaking by the medical profession to preserve confidentiality is to safeguard patient's dignity, privacy and autonomy and this obligation extends even after the death of the patient. ${ }^{1}$ Nevertheless, the patient's interest in his privacy must be balanced with other potentially conflicting interests. Therefore, there are certain circumstances where the duty of confidentiality may not to be an absolute. There may be countervailing moral or legal considerations to override the duty of confidentiality. In other words, there may be instances where there is a need to violate the general duty to maintain confidentiality and when circumstances demand for the disclosure of certain information.

\section{THE DUTY OF MEDICAL CONFIDENTIALITY AND ITS JUSTIFICATIONS}

The duty of confidentiality refers to the legal or ethical duty to keep private the information gathered during the course of a professional relationship. ${ }^{2}$ Literally speaking, confidentiality means to keep a secret that is not to be divulged. ${ }^{3}$ All identifiable patient information, whether written, computerised, visual or audio recorded or held in the memory of medical professionals, is subject to the duty of confidentiality. These include (i) any clinical information about an individual's diagnosis or treatment; (ii) a picture, photograph, video,

Peter De Cruz, Comparative Healthcare Law (London: Cavendish Publishing, 2000), 47.

2 British Medical Association (BMA). (n.d), Confidentiality and Disclosure of Health Information Tool Kit. London: BMA., accessed March 2,2016,http://bma.org.uk/practical-support-at-work/ethics/confidentiality-andhealth-records/confidentiality-tool-kit.

3 Puteri Nemie Jahn Kassim, Nursing Law and Ethics (Kuala Lumpur: International Law Book Services, 2012), 209. 
audiotape or other; (iii) images of the patient; (iv) the identity of the patient's doctor and the information about the clinics the patients had attended; (v) anything else that may be used to identify patients directly or indirectly so that any of the information above, combined with the patient's name or address or full postcode or the patient's date of birth, can identify be made to them. ${ }^{4}$

The duty of confidentiality serves various purposes in medicine. Firstly, confidentiality gives recognition to patient autonomy. It acknowledges respect for the patient's sense of individuality and privacy. ${ }^{5}$ A patient's personal, physical, and psychological secrets are kept confidential in order to decrease the sense of shame and vulnerability that would surface if the information would be revealed, particularly, for conditions that may be stigmatizing such as sexual and reproductive health as well as psychiatric health concerns. ${ }^{6}$ Secondly, confidentiality protects doctor's integrity, which is important in improving the patient's health. Confidentiality permits individuals to trust that information given to their doctors will not be dispersed further. In doing so, communication will become honest and straightforward. If patients did not believe that doctors would keep their secrets then they could not only refuse to divulge embarrassing information but also hold back potentially medically important information, thus, reducing their chances in getting the best medical care. ${ }^{7}$ In many psychiatric cases for example, confidentiality is essential to psychiatric treatment. Without the assurance of complete secrecy, patients would be less inclined to enter into treatment and those already in therapy would be unwilling to disclose important material. Therefore, violating confidentiality would seriously affect the care of the mentally ill, to the detriment of patients and the society as a whole.

\footnotetext{
British Medical Association (BMA). (n.d). Confidentiality and Disclosure of Health Information Tool Kit. London: BMA.

5 Puteri Nemie, Nursing Law and Ethics, 210.

6 Jessica De Bord, Confidentiality Ethics in Medicine (Washington: University of Washington School of Medicine, 2013).

7 Gillon, R. Philosophical Medical Ethics (Chichester: John Wiley, 1986).
} 


\section{ETHICAL OBLIGATIONS RELATING TO THE DUTY OF MEDICAL CONFIDENTIALITY}

Medical ethics has regarded the duty of medical confidentiality as one on the core and non-negotiable tenets of medical practice. The ethical duty of medical confidentiality was first articulated in the Hippocratic Oath which takes the form of a covenant comprising of a code of medical ethics and professional etiquette. ${ }^{8}$ The Oath imposes a strict duty of confidentiality for doctors by stating that:

What I see or hear in the course of the treatment or even outside of the treatment in regard to the life of men, which on no account one must spread abroad, I will keep to myself holding such things shameful to be spoken about. ${ }^{9}$

Thus, doctors should not divulge information gathered during the course of their professional relationships with their patients or even those gathered outside of the medical activities. ${ }^{10}$ Thus, the ethical obligation of the duty stems from the special relationship of trust and confidence created between the doctor and the patient. Patients disclose personal information about themselves while seeking advice, care and treatment from the medical professionals believing and trusting that they are able to help them. Without the element of trust, the patient would be inhibited from disclosing important information about their medical condition which may be private, embarrassing and stigmatising if they are made known to the public. ${ }^{11}$ Thus, it would only be fair for the doctor to hold such special information in confidence and to use it exclusively for the benefit of the patient.

The ethical obligation of medical confidentiality laid out by the Hippocratic Oath has been accepted globally in substance and embedded in a variety of modernised versions of codes of medical ethics. For instance, the International Code of Medical Ethics mentions that:

8 Ben White, Fiona McDonald \& Lindy Willmott, Health Law in Australia (New South Wales: Thomson Reuters, 2014), 373-374.

9 L. Edelstein, Ancient Medicine (Baltimore: Johns Hopkins University Press, 1987), 6.

10 White, McDonald \& Willmott, 372.

$11 \quad$ See Stephens v Avery [1988] 2 All ER 477. 
A doctor shall preserve absolute secrecy on all he knows about his patients because of the confidence entrusted in him.

Meanwhile the Declaration of Geneva, which is the basis of the modern version of the International Code of Medical Ethics, ${ }^{12}$ requires doctors to promise to respect the secrets that have been confided in them even after the patient has died. ${ }^{13}$ Similarly, under provision 2.2 of the Malaysian Medical Council Code of Professional Conduct 1986, the ethical duty of can be found in Part II of Infamous Conduct which states under the heading "Abuse of Confidence" that:

A practitioner may not improperly disclose information which he obtains in confidence from or about a patient.

Further, provision 3.5 of the Code of Professional Conduct for Nurses 1998 by the Nursing Board Malaysia specifically provides that:

The nurse must not disclose information which she obtained in confidence from or about a patient unless it is to other professionals concerned directly with the patient's care.

Nevertheless, the duty of medical confidentiality, like other ethical duties, is not absolute. There are instances where this duty can be overridden in order to protect individuals or the public when the law requires it. Nevertheless, before disclosing a patient's information, the doctor should make every effort to discuss the issue/s with the patient. If disclosure of the information is necessary, it should be done in a way that minimises harm to the patient and heeds the governing legal conditions allowing disclosure of such information.

\section{THE RULES OF CONFIDENTIALITY UNDER MEDICAL LAW}

The source of the obligation of confidentiality can further be found in the common law, principles of equity and various statutory provisions. While the ethical duty of confidentiality is universal, the

\footnotetext{
12 Hau Kong-lung, "Law and Ethics in Medical Practice: An Overview", Medical Section, 8(6) 2003: 3-4.

13 De Cruz, 47.
} 
legal concept of confidentiality may not be uniformly recognised or applied in all jurisdictions. Generally, the medical professional has a duty in law not to voluntarily disclose, without the consent of the patient, information which he has gained in his professional capacity. ${ }^{14}$ Thus, any improper release of personal information by the doctor may trigger a legal action by the patient. Under the common law, the duty of confidentiality is well established and can be found in both contract and tort law.

In contract law, every contract between a patient and a doctor gives rise to an implicit agreement that the professional will preserve the patient's confidences, and breach of this obligation could give rise to an action for breach of contract. In circumstances where the patient pays for the treatment, the relationship between the doctor and the patient is contractual and the patient has a right to sue for breach of contract as long as the damage is not too remote. ${ }^{15}$ There is thus, an implied term in the contract between the doctor and the patient that the patient's affairs are confidential and the information about the patient will not be disclosed without just cause. ${ }^{16}$

Alternatively, the patient may also have a remedy in the tort of negligence against a doctor, if negligent disclosure of confidential information gives rise to some foreseeable injury to the patient. In $A G$ $v$ Guardian Newspapers (No 2, ${ }^{17}$ Lord Goff stated:

.... a duty of confidence arises when confidential information comes to the knowledge of a person (the confidant) in circumstances where he has notice, or is held to have agreed, that the information is confidential, with the effect that it would be just in all the circumstances that he should be precluded from disclosing the information to others... ${ }^{18}$

His Lordship however, added several limitations to this duty. The first limitation is that, "the principle of confidentiality only applies to information to the extent that it is confidential." Thus, once the information has entered the public domain, it can no longer be regarded as confidential. The second limitation is that, "the duty of confidence applies neither to useless information, nor to trivia..."

\footnotetext{
See Hunter v Mann [1974] QB 767.

White, McDonald \& Willmott, 381.

Breen $v$ Williams (1996) 186 CLR 71, para. 9.210.

[1990] AC 109

$A G v$ Guardian Newspapers (No 2) [1990] AC 109, 281.
} 
The third limitation is of far greater importance and is basically the subject-matter of this article. Although the duty of confidentiality protects public interests for protection of confidentiality, but the duty can be overridden by some other countervailing public interest, which favours disclosure. ${ }^{19}$

The duty of medical confidentiality can also be found under the principles of equity relating to elements of morality governing all interpersonal relationships. ${ }^{20}$ As patients invariably confide intimate personal details about themselves, the provision of such confidential information may make the relationship between the patient and the doctor fiduciary in nature. ${ }^{21}$ However, the relationship may not be fiduciary for all purposes as a person may stand in a fiduciary relationship to another for one purpose but not for others. ${ }^{22}$ Classes of information that can be protected include information about:

(a) health and medical treatment;

(b) sexual life;

(c) appearance;

(d) identity;

(e) private acts;

(f) knowledge of or involvement in crime;

(g) financial and business information;

(h) the contents of personal communications and conversations. ${ }^{23}$

Further, equity will also intervene where confidential information has been obtained by mistake, inadvertently, surreptitiously, improperly ${ }^{24}$ or "where the person to whom the confidential information has been disclosed seeks to use it in breach of the terms on which it was disclosed and to the detriment of the party who communicated the confidential information. $" 25$

$A G v$ Guardian Newspapers (No 2) [1990] AC 109, 282.

Stephens v Avery [1988] 2 All ER 477, 482.

Breen v Williams (1996) 186 CLR 71, 107-108.

Hospital Products Ltd v United States Surgical Corporation (1984) CLR 41, 98.

Manique Cooray, "Information Gathered on Social Networking Sites and the

Law of Confidence", International Conference on Social Science and Humanity.

IPEDR. (Singapore: IACSIT Press, Vol.5, 2011), 50.

24 White, McDonald, \& Willmott, 381-382.

25 Trevorrow v South Australia (No. 4) (2006) 94 SASR, paragraph [14]. 


\section{THE EXCEPTIONS PROVIDED BY THE LAW}

Although the basis of the law's protection of confidence is that there is a public interest that confidences should be preserved and protected by law, nevertheless, as has been stated earlier, this public interest may be outweighed by some other countervailing public interest which, favours disclosure. ${ }^{26}$ The Malaysian Medical Council Revised Guidelines 2011 on Confidentiality stated that a practitioner may:

disclose personal information if,

(a) it is required by law

(b) the patient consents, either implicitly for the sake of their own care, or expressly for other purposes; or

(c) it is justified in the public interest. ${ }^{27}$

Therefore, the duty of confidentiality is not absolute and the law recognises several exceptions to the general rule of protecting confidentiality. The exceptions include:

\section{(i) Disclosure with Patient's Consent}

Confidential information regarding the patient may be disclosed if the patient agrees for its disclosure through an express or implied consent. Explicit or express consent is achieved when a patient actively agrees, either orally or in writing, to a particular use or disclosure of information, which has been discussed with the patient. ${ }^{28}$ In procuring an express or explicit consent, the patient needs give a legally valid consent. This means patient must have the mental competence (reached the age of majority and of sound mind), sufficient understanding of the treatment proposed (the consent must be informed in nature) and by with their own free will. ${ }^{29}$ In other words, there must not exist any duress or undue influence. ${ }^{30}$

\footnotetext{
26 AG v Guardian Newspapers (No 2) [1990] AC 109 at. 282, per Lord Goff

27 MMC Guidelines 2011, at Provision 3.

28 British Medical Association (BMA). (n.d). Confidentiality and Disclosure of Health Information Tool Kit. London: BMA

29 Puteri Nemie Jahn Kassim, Law and Ethics Relating to the Medical Profession (Kuala Lumpur: International Law Book Services, 2007), 20.

30 See Re T (Adult: Refusal of Medical Treatment) [1992] 4 All ER 649.
} 
Patient agreement can also be implied, signaled by the behaviour of an informed patient. ${ }^{31}$ In certain situations, the release of patient information may be implied, particularly, to individuals within a health facility who have legitimate therapeutic interest for accessing the information in order to be able to provide the appropriate care and treatment. ${ }^{32}$ However, the issue of implied consent may be contentious, particularly, when there is lack of understanding of the implications of the disclosure by the patient or it violates the patient's right of privacy. Even if the information has been procured within a clinical environment for the best interest of the patient, the patient still needs to be informed explicitly in all aspects of the medical procedure. This can be seen in the case of Lee Ewe Poh v Dr Lim Teik Man \& Anor, ${ }^{33}$ where the patient brought an action against a colorectal surgeon who took photographs of her private parts without her consent during a procedure was held to constitute an invasion of her privacy rights under the common law. The photographs were taken while the patient was unconscious and under anaesthesia. The patient later learned from the nurse that photographs showing her anus were taken without her prior knowledge and consent. The surgeon claimed that "infringement, invasion or violation of privacy" was not a recognised tort or a cause of action in Malaysia. It was acceptable medical practice for photographs to be taken in the course of surgical procedure in a clinical environment and intended for the patient's medical record. It was further submitted that the patient's identity was not known in these photographs. However, the court held that consent was an absolute requirement especially since the photographs involved images of her intimate parts. Invasion of privacy of a female in relation to her modesty, decency and dignity is a cause of action and thus, actionable. ${ }^{34}$ As a doctor, the surgeon ought to be aware of the need to obtain the patient's prior consent for such photographs to be taken, particularly, when it involves the private parts of the patient. Further, there was publication of the photographs as the photographs were seen by the nurse. This case

31 British Medical Association (BMA). (n.d). Confidentiality and Disclosure of Health Information Tool Kit.

32 Malaysian Medical Council (MMC), Revised 2011 Guidelines on Confidentiality, accessed February 1, 2016. http:// mmc.gov.my/v1/docs/Confidentiality.pdf.MMC Guidelines 2011, provisions 22 -24.

33 [2011] 1 MLJ 835.

$34 \quad$ See Maslinda bt Ishak $v$ Mohd Tahir bin Osman \& Ors [2009] 6 MLJ 826. 
depicts that the right of privacy of the patient needs to be fully respected in modern health care setting and prior consent of the patient is essential and cannot be taken for granted. Implied consent is not a lesser form of consent but in order for it to be valid, it is important that patients are made aware that information about them will be shared, with whom it will be shared, and that they have the right to refuse. Even when the practitioner have contractual obligations with the third parties such as insurance companies or managed care organisations, the practitioner shall obtain the patient's consent before undertaking any examination or writing a report for a third party and ensure that the patient's consent is obtained prior to the submission of the report. ${ }^{35}$

\section{(ii) Disclosure Allowed by Statutes}

A number of statutory provisions provide for the disclosure of information by doctors. For instance, there are several legislations in Malaysia that requires medical practitioners to disclose patient information to the relevant authorities, for example, the Prevention and Control of Infection Diseases Act 1988 (Act 342), the Poisons Act 1952 (Act 366) (sections 21(2), 23(2) and 24; Regulations 19 and 20 of the Poisons (Psychotropic Substances) Regulations 1989) and the Criminal Procedure Code (FMS Chapter 6). For instance, section 10(2) of the Prevention and Control of Infection Diseases Act 1988 requires medical practitioners to provide information of infectious diseases to the nearest Medical Officer of Health in the prescribed form. Similarly, section 27 of the Child Act 2001 states that:

[I]f a medical officer ... believes on reasonable grounds that a child he is examining or treating is physically or emotionally injured as a result of being ill-treated, neglected, abandoned or exposed, or is sexually abused, he shall immediately inform the Protector" ${ }^{36}$ and failing to comply with this, the medical officer "commits an offence and shall on conviction be liable to a fine not exceeding two years or to both. ${ }^{37}$

MMC Revised 2011Guidelines on Confidentiality, provision 29.

Section 27(1) of the Child Act 2001.

Section 27(2) of the Child Act 2001. 


\section{(iii) Disclosure in the Public Interest to Prevent Harm to Others}

The influence of principles based on public interest is predominant in the action for the breach of confidence. ${ }^{38}$ Public interest includes matters, which affects the life and even the liberty of members of the society. ${ }^{39}$ If it can be shown that the public has serious and legitimate interest in the disclosure then it may be demonstrated that there is a just cause or excuse in breaking confidence. The importance of secrecy is weighed against the public interest in disclosure. However, before considering whether a disclosure of personal information in the public interest would be justified, the practitioner must be satisfied that identifiable data are necessary for the purpose, or that it is not practicable to anonymise the data. In such cases the practitioner shall still try to seek patient's consent, unless it is not practicable to do so, for example because:

(a) the patients are not competent to give consent; or

(b) the records are of such age and/or number that reasonable efforts to trace patients are unlikely to be successful; or

(c) the patient has been, or may be violent; or obtaining consent would undermine the purpose of the disclosure (e.g. disclosures in relation to crime); or

(d) action must be taken quickly (for example in the detection or control of outbreaks of some communicable diseases) and there is insufficient time to contact patients. ${ }^{40}$

Nevertheless, "ultimately, the 'public interest' can only be determined by the courts". 41

Public interest was raised as a defense in the English case of $X v$ $Y^{42}$ which concerned doctors who continued to practice medicine despite having developed Acquired Immune Deficiency Syndrome (AIDS). The court held that the public interest in preserving the confidentiality of hospital records identifying actual or potential

Francis Gurry, In Breach of Confidence. (Oxford: Clarendon Press, 1987).

Stephen De Bate, "A Mole's Charter?: A Review of Recent Public Interest

Defence Cases”, Law Society's Gazette. 84 (14) (1987): 1048.

40 MMC Revised 2011Guidelines on Confidentiality, provision 35.

41 MMC Revised 2011Guidelines on Confidentiality, provision 38.

42 [1988] 2 All ER 648. 
AIDS sufferers outweighed the public interest in having access to such information through the press. This is because to publish such information could lead to victims of the disease being deterred from coming forward and obtaining treatment in hospitals for fear for discovery. Furthermore, free and informed public debate about AIDS could take place without publication of the confidential information. Amongst other examples of public interests, which may outweigh the competing public interest in maintaining confidences are disclosure in the interests of national security, disclosure to prevent harm to third party and disclosure to prevent crime.

Medical professionals including psychiatrists may, at times, find it necessary to reveal confidential information disclosed by the patient in order to protect the patient or third parties from imminent danger. In these cases, the harm sustained by the third party may outweigh the duty of confidentiality owed by the doctor to the patient. The case of Tarasoff $v$ Regents of the University of California, ${ }^{43}$ illustrates that the duty of confidentiality can be overridden in the interests of the public. In this case, the patient confided to his therapist, an employee of the University of California, of his intentions to harm a fellow colleague, Tatiana Tarasoff, who had constantly rejected his advances. The therapist informed the police but did not inform Tarasaff herself. Tarasoff was later found dead, stabbed to death by the patient. $\mathrm{Mr}$ Justice Tobriner, holding the majority opinion in the Supreme Court of California held that there was a duty by the therapist to disclose threats made by the patient to Tarasoff. If the patient presents a serious danger of violence to another, the therapist incurs an obligation to use reasonable care to protect the intended victim against such danger. The discharge of this duty may require the therapist to take one or more of various steps, depending upon the nature of the case, which may include warning the intended victim or others likely to apprise the victim of the danger, to notify the police, or to take whatever other steps are reasonably necessary under the circumstances. 44

(1976) 551 P 2d 334.

44 Tarasoff $v$ Regents of the University of California (1976) $551 \mathrm{P} 2 \mathrm{~d} 334,340$. Th English courts in Hill v Chief Constable of West Yorkshire [1988] 2 All ER 238 and Home Office v Dorset Yacht Co Ltd [1970] 2 All ER 294 have applied close guarded principle of foreseeability and proximity. In order to impose liability, an identifiable victim would be an essential requirement together with a special distinctive risk in relation to the victim, which ought or have been foreseen by the defendant. 
Hence, disclosure may be justified on the basis of the need to protect those at risk of death or serious harm. The protection of public from crime was also considered in the English case of W v Egdell, 45 which provides an interesting insight into the dilemma faced by the court in such situation. In this case, W, a paranoid schizophrenic, was detained as a patient in a secure hospital indefinitely following a conviction of manslaughter on the grounds of diminished responsibility and could only be released by the order of the Home Secretary if he was found to be no longer a danger to public safety. Ten years after his detention, $\mathrm{W}$ made an application to the mental health tribunal to review his condition and hope that this will lead to an early discharge. Dr. Egdell, a consultant psychiatrist, was asked by W's solicitors to prepare a psychiatric report on W. After examining $\mathrm{W}$, Dr Egdell opined that $\mathrm{W}$ is still highly dangerous and showed persistent interest in explosives. Upon receiving the report, W's solicitors withdrew his application to the mental health review tribunal. However, Dr. Egdell believed that the contents of his report should be made available both to the medical director of the hospital that was caring for $\mathrm{W}$ and the Home Office. This is to warn those who are involved in caring for $\mathrm{W}$ at the hospital and to ensure that the public was in no way endangered by his early release. W applied to the court for an injunction preventing the disclosure of the report by Dr. Egdell. The Court of Appeal refused to prevent disclosure of the report and held that public interest justified disclosure to the medical director and the Home Office. The report contained the dangerousness of $\mathrm{W}$ that is not known to many. To suppress it would have prevented material relevant to public safety from reaching the authorities responsible for protecting it. It was in the public interest to ensure that they took decisions on the need for such protection on the basis of the best available information. Bingham LJ. remarked that a balance should be struck between the public interest in maintaining professional confidences and the public interest in protecting the public against possible violence. He aptly said that:

The breach of such a duty [of confidentiality] is...dependent on circumstances...the law recognizes an important public interest in maintaining professional duties of confidence but the law treats no such duties as absolute.... [it can] be overridden where there is held to be a stronger public interest in disclosure.... Dr Egdell did act in 
accordance with the law and his conduct was necessary in the interest of public safety and the prevention of crime. ${ }^{46}$

The decision in $W v$ Egdell has been applied in Public Prosecutor $v$ Dato' Seri Anwar bin Ibrahim \& Anor., ${ }^{47}$ where the court held that there is no privilege under the law for a doctor to refrain from disclosing what transpired between him and his patient. ${ }^{48}$ In this case, the court held that Dr. Fadzil did not commit a breach of his duty of confidentiality when he disclosed what transpired between him and his patient, Sukma. He concluded that Sukma was suffering from mental depression due to biological factors and family background. He further disclosed that Sukma told him that he had homosexual relationships with his adopted brother and his business partner although he did not disclose the identity of these two persons. The implication of these cases depict that, in exceptional circumstances, the duty of confidentiality could be breached. However, for disclosure to be lawful, there must be an overwhelming public interest in disclosure. A real and serious risk of danger to the public must be shown before the public interest exception is made out and the public interest exception can only justify disclosure so long as the threat persists.

\section{DISCLOSURE OF HIV/AIDS STATUS}

As discussed above, even where public interest requires disclosure, it is necessary to confine it to the extent strictly necessary. The fact that it is in the public interest to reveal some aspects of a patient's situation does not justify disclosing all the details. ${ }^{49}$ However, this does not prevent revealing information that helps to explain the situation. Disclosure of patients with HIV status has been a concern particularly, to those caring for them and to their sexual partners. Under the common law, disclosure of a patient's HIV status is allowed provided that two conditions are satisfied: first, that there is a real risk to the people to be informed; secondly, that disclosure is the

\footnotetext{
$46 \quad W v$ Egdell [1990] 1 All ER 835, 851-852.

47 [2001] 3 MLJ 193.

48 See PP v Haji Kassim [1971] 2 MLJ 115.

49 Jonathan Montgomery, Healthcare Law (Oxford: Oxford University Press, 2003), 269.
} 
only practical way to protect them. The General Medical Council in England advises doctors to explain to patients the nature and implications of their disease, how they can protect others from infection and the importance of giving professional carers information about their condition. However, if patients still refuse to allow others to be informed of their status, disclosure is accepted as ethical provided that the doctor believes that there is a serious risk of death or serious harm and that patients are told that the information will be disclosed. ${ }^{50}$ Stigma and discrimination are usually inherent in society's perception towards HIV patients. A study which was conducted in 2012 by Positive Malaysian Treatment Access \& Advocacy Group revealed that $15.6 \%$ of the people living with HIV respondents had suffered discrimination in relation to job or income, with $12.4 \%$ being refused employment and $6.4 \%$ having been refused promotion or having the nature of their job changed. ${ }^{51}$ Thus, it is of paramount importance that the medical profession is careful and discreet in releasing information about HIV patients, even to companies, insurance companies and managed care organisations without patient's prior consent. The Malaysian HIV/AIDS Charter for Doctors states that "doctors should, without prejudice and discrimination, when carrying out blood or other tests, ensure that adequate pre and post-test counselling is conducted to ensure consent to testing." The Charter further reads that patients who are HIV positive shall be encouraged to inform the attending doctor/s of their HIV status and information about a patient's HIV status shall be restricted to medical professionals and other authorised personnel on a need-to-know basis.

\section{BREACHING THE DUTY OF CONFIDENTIALITY THROUGH SOCIAL NETWORKS}

The obligation of confidentiality is not limited to the undertaking of not divulging confidential information but also includes a responsibility to make sure that all records containing patient

\footnotetext{
50 General Medical Council (GMC). Serious Communicable Diseases. (London: GMC, 1997), paragraphs 18-23.

51 Gurusamy, J. "Employment and Education: Are We Stigmatising and Discriminating HIV Patients?” Berita MMA. (Vol.44 (March), 2014), 20-21.
} 
information are kept securely. Confidential records should not be left where other people may have casual access to them and information about patients should be sent under private and confidential cover, with appropriate measures to ensure that it does not go astray. The use of social networks has been beneficial for the medical profession to interact with patients, market their practices, attract participants for research studies and share information with colleagues and community. ${ }^{52}$ Nevertheless, the discussions on patients' information over social networks may trigger a myriad of legal issues particularly, on the law relating to privacy and defamation. Thus, it has become increasingly vital for medical professionals to be aware of the related legal risks ${ }^{53}$ and be extremely cautious in deciding what information to share on their social network sites. The same legal rules on confidentiality apply to the information disseminated through social networks. In view of the vulnerabilities of such information, healthcare providers as employers, should enact policies with guidelines and requirements for their employees' online interactions to ensure that their employees are aware of the risks of posting confidential or proprietary information and set standards for appropriate and professional communications. ${ }^{54}$ The British Medical Association has developed specific guidelines for medical practitioners in order to determine situations which would require them to disclose information through social network. ${ }^{55}$ The 2011 BMA Guidelines states that it is a breach of General Medical Council standards to disclose identifiable information about patients without their consent on blogs, medical forums or social networking sites. Such a breach could give rise to legal action from patients. ${ }^{56}$ Aside from that, even unintentional disclosure is considered improper as medical professionals should not share identifiable information about patients where it may be overheard or read, including in internet forums. ${ }^{57}$ The BMA further recommends that medical professionals

52 Dill K.J. "Social Networking Sites Present Legal Risks for Health Care Providers". Healthcare Law Update. accessed April 10, 2016, http://www. pepperlaw.com, 2009.

53 Cooray, 49.

54 Dill KJ, 2009.

55 British Medical Association (BMA), Using Social Media: Practical And Ethical Guidance For Doctors And Medical Students. First edition. (London: British Medical Association, 2011).

56 Ibid.

57 General Medical Council (GMC). Confidentiality. London: GMC, 2009). 
consider adopting conservative privacy settings where available, for instance, social media sites such as Twitter and Facebook, have privacy settings that allow users to control and put restrictions on who has access to their personal information. ${ }^{58}$ However, the medical professional should also be aware that not all content on the web can be protected in this way and thus, they need to be conscious at all times of those having access to their personal material online and how widely will the content be shared. ${ }^{59}$

The Malaysian Ministry of Health has recently introduced specific "Guidelines for the Use of Social Media among Healthcare Providers" which came into effect on $31^{\text {st }}$ March 2016. According to provision 1.4 of the 2016 Guidelines, it aims to, "provide practical and ethical advice on different issues that healthcare providers in the Ministry of Health may encounter when using social media for consultation to minimize the risk of ethical and legal complications". Thus, provision 4.1 further states that all patient identifiable information shall be excluded from any information transmitted through social media. Therefore, uploading and transmitting of still images or in video format shall not include any patient identifiable information such as name, registration number, IC and address for example ECG tracing, laboratory results or radiological images. According to provision 5.1, it is the duty of the person in charge of the health facility such as the hospital director and the head of department to ensure that all healthcare providers are aware of the existence of the guidelines. The 2016 Guidelines should also be read together with related provisions under the Malaysian Medical Council (MMC) Guidelines 2011 pertaining to issues on disclosing information through social network. ${ }^{60}$ For example, provision 7 of the 2011 Guidelines states that "the medical practitioner shall take steps to ensure that the patient's confidentiality is maintained regardless of the technology used to communicate health information" and "shall not discuss patient's information in an area where the medical practitioner can be overheard or leave patient's records, either on paper or on screen, where they can be seen by other patients, unauthorized health care staff or the public". The medical practitioner has a responsibility, as a custodian of patient's medical records, to ensure the integrity, confidentiality and availability of the medical

\footnotetext{
58 BMA Guidelines, 2011.

59 Ibid.

60 MMC Revised 2011Guidelines on Confidentiality, provision 4.4.
} 
records ${ }^{61}$ and follow the MMC's guidelines on raising concerns about patient safety, including concerns about confidentiality and information governance. ${ }^{62}$

\section{THE RULE OF CONFIDENTIALITY UNDER ISLAMIC LAW}

Islam holds the right of privacy of human beings in high esteem and this right is given paramount and important consideration under the Shari'ah. There are numerous Qur'anic verses and hadiths explaining the significance of privacy in Islam. Surah an-Nur, verse 27 stresses on physical privacy in which Allah s.w.t states to the effect:

O you who believe! Enter not houses other than your own, until you have asked permission and saluted those in them, that is the best for you, in order that you may heed (what is seemly). ${ }^{63}$

Further, in Surah al-Hujurat verse 12, Allah s.w.t. states to the effect that:

O you who believe! Avoid suspicion as much as possible, for suspicion in some cases is a sin. And spy not on each other, nor speak ill of each other behind their backs. ${ }^{64}$

The rule to respect one's privacy is not an obligation imposed on adults only but applies to children as well. In Surah an-Nur, verse 59, Allah s.w.t states to the effect:

But when children among you come of age, let them (also) ask for permission as do those before them, does Allah s.w.t. make His signs to you, for Allah s.w.t is full of knowledge and wisdom. ${ }^{65}$

Thus, Muslims are strictly advised not to indulge in activities that will bring another Muslim's name, reputation and business in contempt. The Prophet Muhammad (peace be upon him) has also stated that "The believer is not one who defames, slanders, nor is

\footnotetext{
61 Ibid, provision 11.

62 Ibid, provision 9.

63 The Holy Qur'an, 4: 27.

64 The Holy Qur'an, 49:12.

65 The Holy Qur'an, 4:59.
} 
obscene". ${ }^{66}$ Guided by the respected principle of privacy in Islam, medical professionals are forbidden to disclose information they obtain from their patient to others. The Islamic Charter of Health Ethics provides that:

A doctor may not disclose a personal secret that has come to his knowledge through the performance of his profession, whether the patient confides the secret to him, or the doctor comes to know it in the course of his work. ${ }^{67}$

Further, when the doctor receives information from his patient, it is considered part of his amanah (trust) not to disclose the information to others without the patient's permission. Amanah literally means trust, reliability, trustworthiness, loyalty, faithfulness, integrity, and honesty. The concept of amanah binds individuals with society as it defines man's rights and responsibilities in relation to all the other humans, his environment and God's creation. The term amanah is used in the Qur'an and the Sunnah to indicate a very broad and deep meaning. Everything given to us by Allah s.w.t is a kind of amanah (trust) which must be appropriately managed according to the laws and rules revealed by Allah s.w.t ${ }^{68}$ Every responsibility assigned to a person is considered an amanah. Our bodies, our souls, our eyes, our ears, our intellect, our provisions, our clothing, our homes, and all other blessings and bounties of Allah s.w.t. have been given to us as amanah (trust) and has to be either returned back to Allah s.w.t. or used according to His instructions. ${ }^{69}$ Thus, we have to ensure that we used these gifts from Allah s.w.t properly as we will be made accountable about them. In Surah al-Takathur, verse 2, Allah s.w.t states to the effect: "Then on that day you shall most certainly be questioned about the bounties". ${ }^{70}$ Similarly, in Surah al- Isra', verse 36, Allah s.w.t. states to the effect:

66 Sahih al-Tirmidhi, Vol. 28, Hadith No.1977.

67 Islamic Charter of Health Ethics. Accessed January 2, 2016, http://www.emro.who.int/PDF/islamiccharter_MedicalHealthEthics.pdf, Article 29.

68 Sheikh Munawar Haque. The Concept of Amanah (2014), accessed February 28, 2016,http://www.amda.us/khutba_transcripts/Concept_of_Amanah_in_Islam_Sh eikh_Munawar_Haque.pdf. Ibid.

70 The Holy Qur'an: 102:8. 
The hearing, sight and hearts will all be questioned. ${ }^{71}$

The Holy Qur'an also contains many verses reminding mankind not to be disloyal to Allah s.w.t, His Prophet (peace be upon him), and also not to be dishonest to the amanah (trust) delegated unto them. In Surah al-Anfal, verse 27, Allah s.w.t states to the effect: "O you, who believe, do not betray God and His Messenger, and do not knowingly violate your trusts. ${ }^{72}$ Amanah is considered by the Prophet (peace be upon him). as a sign of faith and breaching it is a sign of hypocrisy. Abu Hurairah r.a. narrated that the Prophet (peace be upon him) said: "The signs of a hypocrite are three (a) whenever he/she speaks, he/she tells a lie; (b) whenever he/she promises, he/she always breaks it; (c) whenever he/she is trusted, he/she always proves to be dishonest". ${ }^{73}$ The Prophet (peace be upon him). further stressed on the responsibility of amanah by stating that: "It has been narrated on the authority of Ibn Umar that the Holy Prophet (peace be upon him). said: Beware, everyone of you is a shepherd and everyone is answerable with regard to his flock. The Caliph is a shepherd over the people and shall be questioned about his subjects (as to how he conducted their affairs). A man is a guardian over the members of his family and shall be questioned about them (as to how he looked after their physical and moral well-being). A woman is a guardian over the household of her husband and his children and shall be questioned about them (as to how she managed the household and brought up the children). A slave is a guardian over the property of his master and shall be questioned about it (as to how he safeguarded his trust). "Beware, every one of you is a guardian and every one of you shall be questioned with regard to his trust". ${ }^{74}$ Consequently, true believers are, according to Surah al-Mu'minun, verse 8, in which Allah s.w.t states to the effect: "those who honor their trusts and their contracts." ${ }^{, 75}$ Therefore, when a person receives confidential information during the tenure of his profession, maintaining secrecy of that information is his responsibility. For instance, an employee is the custodian of the property of his employer which he will be

\footnotetext{
The Holy Qur'an, 17:36.

The Holy Qur'an, 8:27.

Sahih Bukhari, Hadith No. 33.

Sahih Muslim, Book 20: Hadith No. 4496.

The Holy Qur'an, 23:8.
} 
answerable for and what is required to be confidential is considered in as a trust. ${ }^{76}$

However, a doctor is allowed to disclose information about his patient according to the following exceptions:

i. If disclosure of a person's secret is done at his own request, which should be in writing or if disclosure of a secret is in the interest of the patient or society;

ii. If the laws in operation require disclosure of the secret, or an order to disclose it is made by a judicial authority;

iii. If the purpose of disclosing the secret is to prevent crime, in which case the disclosure should be strictly to the official authority concerned and to no other party;

iv. If the disclosure of a person's secret is in the interest of the patient's spouse, provided that it is made to the couple, and not to one without the other;

v. If the doctor makes the disclosure in defending himself before a judicial authority at its request and in as much as the defence requires; and

vi. If the purpose of disclosing the secret is to prevent the spread of an infectious disease that would be harmful to society members provided that the disclosure is made only to the concerned health authority. ${ }^{77}$

\section{CONCLUSION}

Striking a balance between the legitimate interests of the community and the rights of individuals is always problematic. No set of rules could completely address many complex issues facing the medical profession. The law must strike the difficult balance of protecting the rights and interests of the individual person while also maintaining the safety and interests of the public at large or any others who may be affected by the actions of individuals. The greater the potential harm to the public, the greater the pressure to curb the actions of an individual. It is a matter of fine balancing, but at the end of the day,

\footnotetext{
76 Sheikh Munawar Haque. The Concept of Amanah, ibid.

77 Article 29, Islamic Charter of Health Ethics. Accessed January 2, 2016, www.emro.who.int/PDF/islamiccharter_MedicalHealthEthics.pdf.
} 
the law must ensure that any "protective privilege should end where public peril begins." 